\title{
Rainfall and human activity impacts on soil losses and rill erosion in vineyards (Ruwer Valley, Germany)
}

\author{
J. Rodrigo Comino ${ }^{1,2}$, C. Brings ${ }^{1}$, T. Lassu ${ }^{1}$, T. Iserloh ${ }^{1}$, J. M. Senciales ${ }^{2}$, J. F. Martínez Murillo ${ }^{2}$, J. D. Ruiz Sinoga ${ }^{2}$, \\ M. Seeger ${ }^{1}$, and J. B. Ries $^{1}$ \\ ${ }^{1}$ Department of Physical Geography, Trier University, Germany \\ ${ }^{2}$ Department of Geography, Malaga University, Spain
}

Correspondence to: J. Rodrigo Comino (s6jerodr@uni-trier.de)

Received: 12 December 2014 - Published in Solid Earth Discuss.: 23 January 2015

Revised: 17 June 2015 - Accepted: 21 June 2015 - Published: 09 July 2015

\begin{abstract}
Vineyards are one of the eco-geomorphological systems most conditioned by human activity in Germany. The vineyards of the Ruwer Valley (Germany) are characterized by high soil erosion rates and rill problems on steep slopes (between 23 and $26^{\circ}$ ) caused by the increasingly frequent heavy rainfall events as well as deterioration due to incorrect land use managements.

The objective of this paper is to determine and to quantify the hydrological and erosive phenomena in one vineyard in Germany during different seasons and under different management conditions (before, during and after vintage).

For this purpose, a combined methodology was applied. Climatic (rainfall depth distributions and return periods), pedological (soil analysis and classification), geomorphological (sediment movements and rills evolution) and biological (botanic marks on the vines) variables were used on the two experimental plots in the village of Waldrach (Trier, region of Rhineland-Palatinate).

The results showed high infiltration rates (near $100 \%$ ) and subsurface flow which were detected by rainfall simulations performed at different times of the year (between September and December). The highest variations of the monitored rills (lateral and frontal movements) were noted before and during vintage, when footsteps occurred concentrated during a short period of time (between September and October). Finally, two maps of soil loss were generated, indicated by botanic marks on the graft union of the vines. $62.5 \mathrm{tha}^{-1} \mathrm{yr}^{-1}$ soil loss was registered in the experimental plots of the new vineyards ( 2 years), while $3.4 \mathrm{t} \mathrm{ha}^{-1} \mathrm{yr}^{-1}$ was recorded in the old one (35 years).
\end{abstract}

\section{Introduction}

Traditionally vineyards are those among ecogeomorphological systems most affected by human activity. Cerdan et al. (2006, 2010) observed, after studying 1350 experimental plots from several authors, that among cultivated areas, vineyards possess the highest erosion rates in Europe $\left(12.2 \mathrm{tha}^{-1} \mathrm{yr}^{-1}\right)$. These problems appear at marginal anthropic environments with steep slopes, with bare soil and unsustainable land management activities (Martínez-Casasnovas et al., 2003; Paroissien et al., 2010).

Flow direction and rhythms of erosive process are manifested with several rills, which divide the hillslopes in different transects (Bryan, 2000; Prashun, 2011). This pattern of parallel rills (Ludwig et al., 1995; Sánchez-Moreno et al., 2012) shows the degradation processes on the vineyards. Vandekerckhove et al. (1998) observed that erosion rates are enhanced by incorrect land practices by vine growers, and they are especially high after heavy and concentrated rainfall events.

In Europe, erosion rates in vineyards are variable: Martínez-Casasnovas and Poch (1998) and MartínezCasasnovas et al. (2002) observed erosion rates in northern Spain of 207 and 302-405 $\mathrm{tha}^{-1} \mathrm{yr}^{-1}$; Tropeano (1983) estimated a soil loss between 40 and $70 \mathrm{t} \mathrm{ha}^{-1} \mathrm{yr}^{-1}$ in northwest Italy; and Wicherek (1991) and Wainwright (1996) observed a soil loss of $30 \mathrm{tha}^{-1} \mathrm{yr}^{-1}$ in France.

Germany has a long tradition in viticulture and terraces on hillslopes along the Mosel, Ahr and Rhine valleys. Unwin (1996) and Auerswald et al. (2009) reported several problems caused by erosion processes in Central Europe. The re- 
sults of soil loss rates from German vineyards showed differences from $0.2 \mathrm{tha}^{-1} \mathrm{yr}^{-1}$ (Richter, 1991) to $151 \mathrm{tha}^{-1} \mathrm{yr}^{-1}$ (Emde, 1992).

For the Mosel Valley, the importance of the connection between precipitations (water and snow) and the soil loss by surface flow mechanisms carried out by Richter and Negendank (1977) and Richter (1975, 1980a, b, 1991). These soils were characterized by increased infiltration rates, gravel and fine mobilized elements, high organic matter proportions and intensive use of agricultural machinery (Hacisalihoglu, 2007).

From an economic point of view, vineyards are a traditional form of land use and constitute one of the main and substantial economic bases of this region (Ashenfelter and Storchmann, 2010). The agricultural cultivation started in Roman times and continued with the constructions of monasteries in the Middle Ages along Central Europe (Urhausen et al., 2011). This dynamic was significantly increased by the intensification of production and harmful tilling of the soil, which led to a reduction in fertility (Boardman et al., 2003; Raclot et al., 2009). The process of expansion began in the 1950s and continued until the 1990s with some substantial transformations in the production methods through the introduction of new machinery (Martínez-Casasnovas et al., 2010). As a consequence, the presence of gullies and rills, soil compaction and alteration of the local biochemical cycle was increased (Van Oost et al., 2007; Quinton et al., 2010).

The importance of land morphology (Fox and Bryan, 2000; Martínez-Casasnovas et al., 2010), soil surface components (Corbane et al., 2008; Ruiz-Sinoga and MartínezMurillo, 2009) and the influence of hydrological properties (Arnáez et al., 2012) on cultivated and abandoned areas were noted by several authors. Erosive dynamics are revealed through different forms, such as natural or anthropic rills and gullies (Poesen et al., 1998) or modern techniques, like rainfall simulation. Small portable rainfall simulators, designed by Cerdà et al. (1997), or the innovations by Ries et al. $(2009,2013 \mathrm{a}, \mathrm{b})$ and Iserloh et al. (2012) are essential tools to analyze the process dynamics of soil erosion and surface runoff in situ and in the laboratory. It provides the possibility to quantify soil erosion rates and to investigate the impact of several factors (slope, soil type, splash effect, raindrops, aggregate stability, surface structure and vegetation cover) on soil erosion with quick and reproducible measurements (Seeger, 2007; Iserloh et al., 2012, 2013a, b).

Great part of all manifestations of erosion forms in the vineyards have the origins in footsteps and wheel tracks, which can significantly modify the natural dynamic of the hillslope (Van Dijck and van Asch, 2002; Materechera, 2009; Arnáez et al., 2012). Rills, inter-rills (Bryan, 2000; Fox and Bryan, 2000) and ephemeral gullies (Nachtergaele, 2001) show a connection between the lateral or vertical expansion and headcut retreat (Martínez-Casasnovas, 2003).

The purpose of this study is to characterize the soil erosion process of vineyards in the Ruwer Valley (Germany).
The objectives are (i) to determinate the hydrological and erosive response of soil; (ii) to compare the soil erosion rates between the recent ( 2 years) and ancient ( 35 years) vine cultivation, with the results of other locations with similar geomorphological characteristics; (iii) to describe and quantify the spatial and temporal development of rills during a particular period with natural rainfall events (between September and December); and (iv) to evaluate the impact of land management before, during and after vintage in connection with rill erosion process. Finally, two spatial and temporal scales of analyses and, consequently, of erosive processes are considered: (i) local scale with simulated rainfalls and (ii) field scale with the monitoring of rills and quantification of soil loss through the botanic marks.

\section{Materials and methods}

\subsection{Study area}

The study area (Fig. 1) is located in the traditional vineyard village of Waldrach in the Ruwer Valley, an affluent of the Mosel River in western Germany (Trier-Saarburg, Rhineland-Palatinate). It is part of the Rhenish Slate Mountains. The Ruwer Valley descends from a plateau formed at the Hünsrück Mountains, from about 500 m.a.s.l. in the south to approximately 200 m.a.s.l. in the north (Richter, 1980b). The work area ranges between 220 and 250 m.a.s.l. The exposures of the hillslopes are fundamentally south-south-west oriented for maximizing the insolation intensity and favouring the phenology of crops (Menzel, 2005).

Two types of vineyards were studied: (i) old (cultivated more than 35 years) and (ii) young (planted less than 1 year ago). Both have the same lithological characteristics. The parent material is composed of (i) primary basin of no calcareous lithology under undulating reliefs with Devonian greywackes, slates and quartzites; and (ii) fines sediments near the Pleistocene rivers (Schröder, 1991).

The annual rainfall depth is $765 \mathrm{~mm}$ and is concentrated in the summer months $(65-72 \mathrm{~mm}$ per month). The lowest monthly precipitation is observed between February and April (50-60 mm per month). Annual average temperature is $9.3^{\circ} \mathrm{C}$, with average maximum values in June, July and August $\left(16.2-17.6^{\circ} \mathrm{C}\right)$ and minimum values in January and December $\left(1.5-2.3^{\circ} \mathrm{C}\right)$. These data allowed the contextualization of this territory with a $C f b$ climate (Köppen and Geiger, 1954).

The soil management of these vineyards was (Eggenberger et al., 1990; Vogt and Schruft, 2000) (i) soil tillage before and after vintage (end of October and beginning of November); (ii) the presence of grass cover along the inter-rows and below grapevines (between 10 and $35 \mathrm{~cm}$ height); and (iii) the use of vine training systems to find equilibrium between leaves and the graft to maximize photosynthesis and sugar 

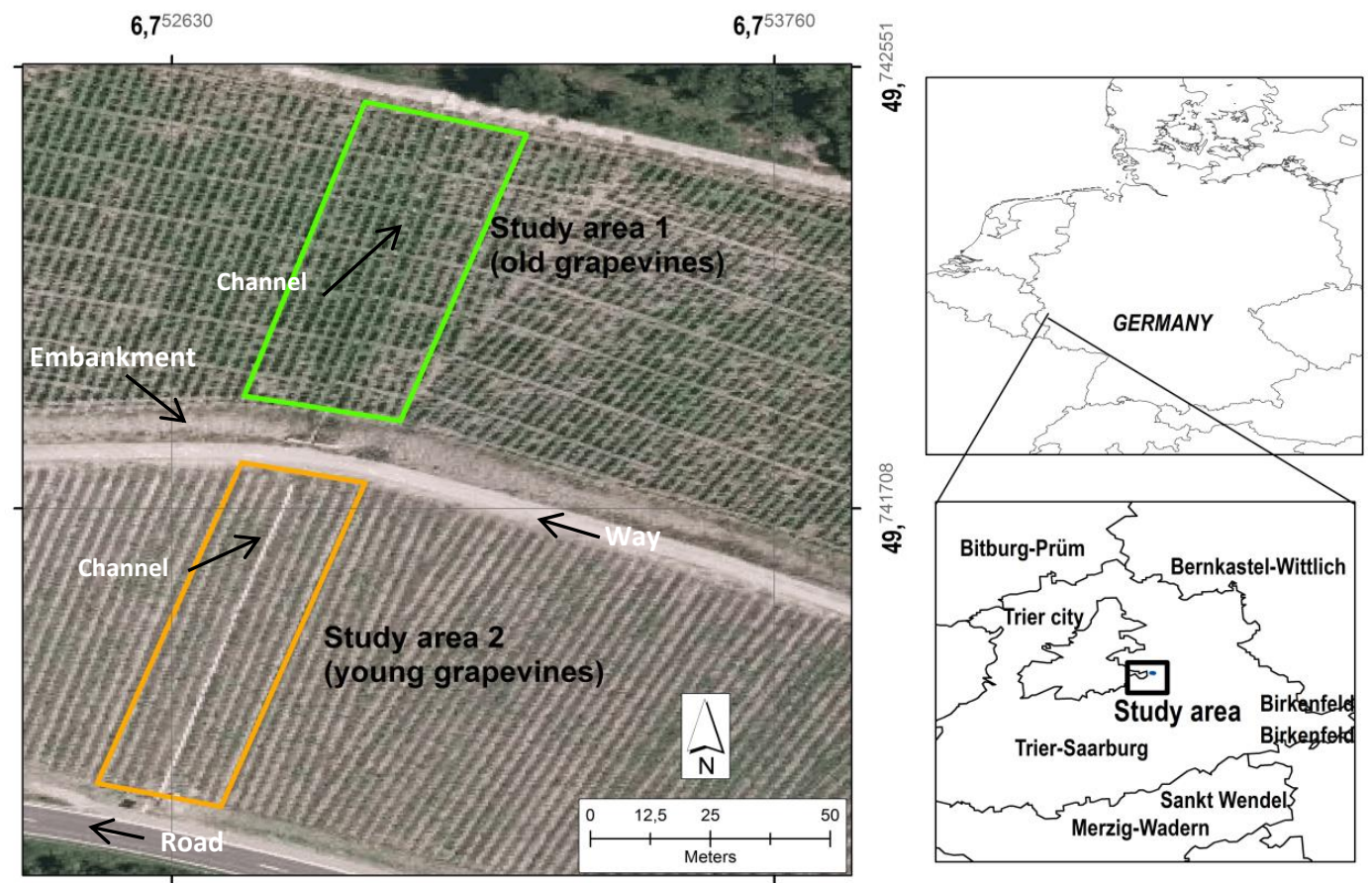

Figure 1. Study area in Waldrach (Ruwer Valley, Germany).

creation, using all of the useful space possible along difficult steep slopes for tilling (between 23 and $36^{\circ}$ ).

Along the embankments and inter-rows, anthropic rills by wheel tracks and footsteps were identified. For example, the monitored rills of this investigation (R1, R2 and R3) are emplaced on the stony embankment (Fig. 1) and were generated by these causes.

\subsection{Soil analysis}

The soil samples were collected from four different places and depths: $0-5$ and $5-15 \mathrm{~cm}$. Along two inter-rows of old and young vineyards and two from the embankments of old grapevines with rills (top and bottom). Each parameter was analyzed with two replicates that were taken in order to determine the soil properties $\mathrm{pH}$, total organic carbon and inorganic carbon content by ignition. The weight loss-onignition method was carried out by applying $430^{\circ} \mathrm{C}(24 \mathrm{~h})$ and $1050^{\circ} \mathrm{C}(6 \mathrm{~h}$ ) in muffle furnace (Davies, 1974; Rossel et al., 2001). Saturation and absorption capacity were measured with a simplification of the method by Emerson (1967), Imeson and Vis (1984) and Herrick et al. (2001) of the waterdrop impact test. Bulk density using steel cylinders of $1 \mathrm{~cm}^{3}$ were calculated. Grain size $(<2 \mathrm{~mm}$ and $>2 \mathrm{~mm})$ was measured as a unique sample joining four different soil samples.

\subsection{Description of rainfall and agricultural events during the monitoring}

Climatic and agricultural actions (during the study period) were monitored to describe the important events in the study area. In order to obtain the rainfall data, an extrapolation of the gradients data at surface level was made by using the data from the peripheral agroclimatic stations of the German Meteorological Service (Deutscher Wetterdienst) and the Dienstleistungszentrum Ländlicher Raum/Rheinland-Pfalz. Due to the lack of a complete climatic data set in the study area, values of rainfall and temperature (all with more than 30 years of data) must be extrapolated from the following (latitude, longitude and altitude above sea level): Mertesdorf (211 m; 49.7722, 6.7297), Hermeskeil (480 m; 49.6556, 6.9336), Trier-Zewen $(131.5 \mathrm{~m} ; 49.7325,6.6133)$, TrierPetrisberg (265 m; 49.7492, 6.6592), Trier-Irsch (228 m; 49.7259, 6.6957), Deuselbach (480.5 m; 49.7631, 7.0556), Konz (180 m; 49.6883, 6.5731), Bernkastel-Kues (120 m; $49.9186,7.0664)$ and Weiskirchen $(380 \mathrm{~m} ; 49.5550,6.8125)$.

Calculations were linear estimations and intersections with the axis using rainfall and elevation data with the software Excel 2010 (Rodrigo Comino, 2013; Senciales and Ruiz Sinoga, 2013). Rainfall events were frequent during all the research period. The daily intensity in this period (September to December) was $2.2 \mathrm{~mm} \mathrm{~d}^{-1}$ and the days with rainfall were 4.6 days in each interval of this monitoring period (between 6 and 7 days). 


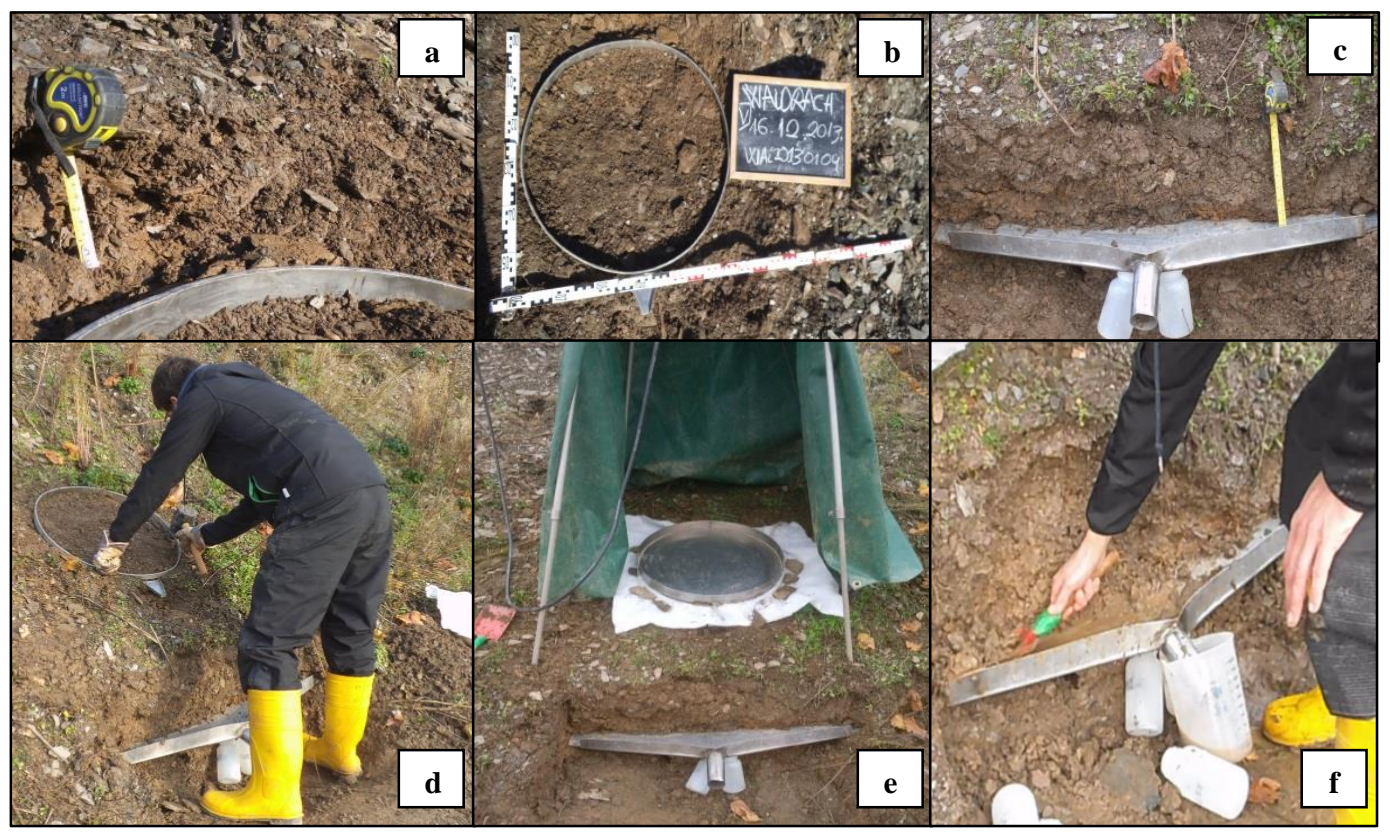

Figure 2. The rainfall simulation in December: (a) A horizon eliminated (between 5 and $7 \mathrm{~cm}$ ); (b) before simulation; (c) profile to $0.5 \mathrm{~m}$ below $(1.5 \mathrm{~m} \times 0.5 \mathrm{~m})$ with the sediment collector; (d) situation of simulator ring; (e) concurrent rainfall simulation, (f) subsurface flow during the experiment.

\subsection{Soil erosion analysis}

A continuation, $K$ (with the soil analysis), and $R$ factor of RUSLE (Wischmeier and Smith, 1978; Dabney et al., 2014) were added to complete the soil analysis and rainfall erosivity respectively (Martínez-Casasnovas et al., 2002). For this purpose, $R$ factor (54.31) was calculated with the index for Germany with better results than adjusted equation for Rhineland-Palatinate region (Sauernborn, 1994; Casper et al., 2013). After that, following the example of Arnáez et al. (2007), recurrence periods with Poisson method, using percentage of days per year with different rainfall depths, were included to justify the intensity of rainfall simulation and classify rainfall events on the study area (Mays, 2011). Results were calculated with the software Excel 2010 and presented as percentage of days per year applying an ordinary co-kriging extrapolation with ArcMap 10.1by autocorrelation and cross-correlation of the heights from the peripheral agroclimatic stations.

\subsubsection{Rainfall simulations}

In alternate varying months, eight rainfall simulations were carried out under different soil moisture conditions. During the first four simulations in August (2012) the soil moisture was between 20 and $30 \%$, while in October and December (2013) it was between 10 and $20 \%$. The objectives were to quantify the soil losses, the degree of infiltration, runoff coefficients and the suspension and concentration of sediments. All simulations were carried out on the inter-rows of old vineyards with the same rainfall intensity $\left(40 \mathrm{~mm} \mathrm{~h}^{-1}\right)$ for two reasons. Firstly, the return period was calculated for different intensities and $40 \mathrm{~mm} \mathrm{~h}^{-1}$ of intensity was the least usual. Therefore, the probability of rainfall greater than $40 \mathrm{~mm} \mathrm{~h}^{-1}$ would be low. Thus, the different reactions of the soil to extreme rainfall could be recorded. Secondly, the simulator was exactly calibrated to control splash effects following Iserloh et al., (2012, 2013a, b). The defined area of experiments coincided with a metal ring of $0.28 \mathrm{~m}^{2}$. To measure the quantity of water, a flow control (Type KSK-1200HIG100, 0-125 L h ${ }^{-1}$, Kobold Company) and a manometer (with a calibrated pressure of 0.2 bar) were applied. In each simulation ( $30 \mathrm{~min})$ we used intervals of 5 min to collect runoff.

From October to November the same results were obtained: total infiltration. Therefore, the last rainfall simulation experiment was carried out in December (2013); to understand the reason of the $100 \%$ infiltration, the stony A horizon was removed inside the metal ring. The main purposes were to (i) confirm the increased infiltration and (ii) investigate the relationship between the process and the soil surface components. A hydrophilic nylon fabric was used to protect the soil from the splash effect. A vertical soil profile was caved underneath the simulator $(50 \mathrm{~cm}$ depth and $150 \mathrm{~cm}$ width) in order to observe the infiltration dynamic. In this manner, subsurface flow was observable (Fig. 2) by the profile and the metal collector; however, it was impossible to quantify it. 


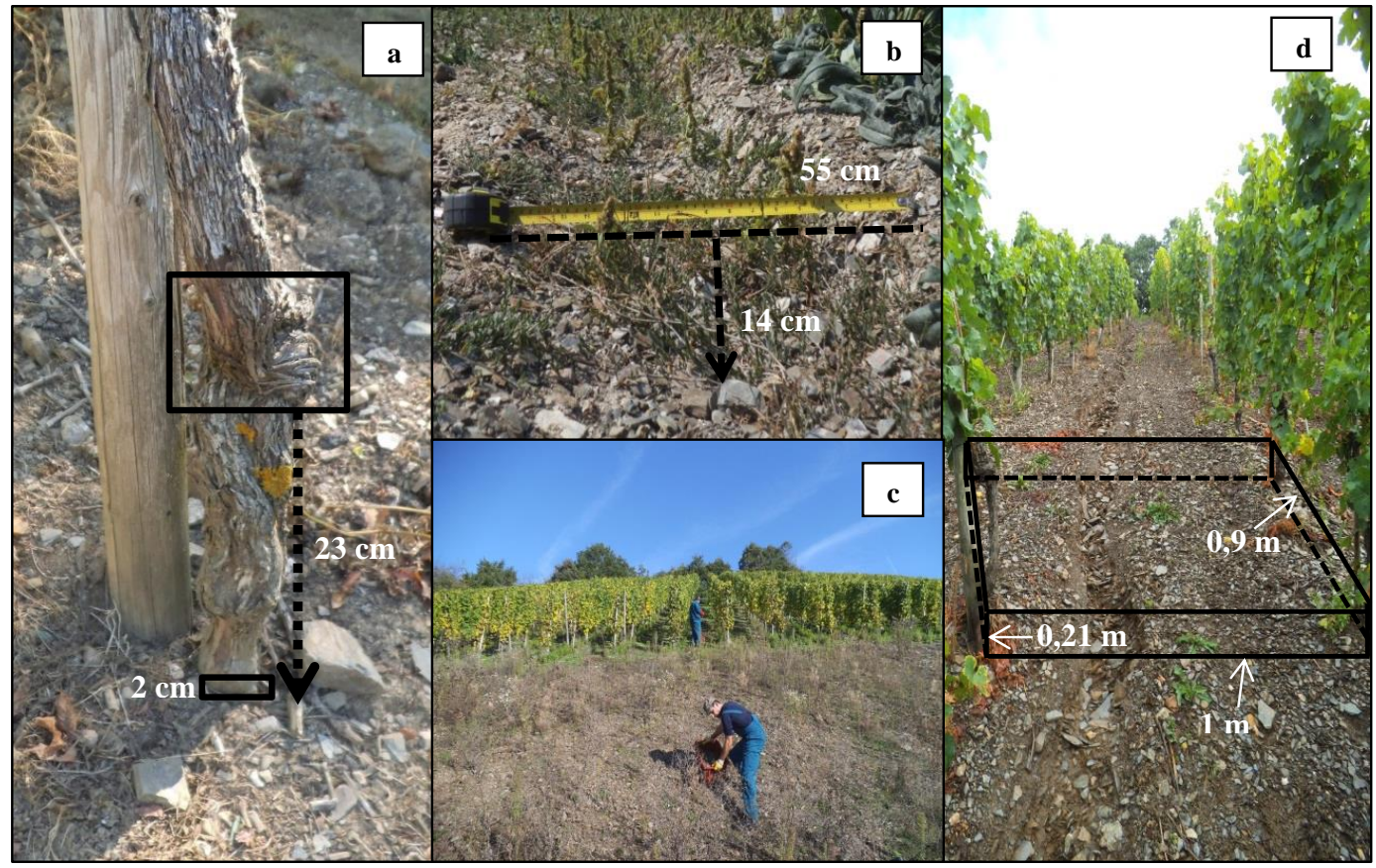

Figure 3. Monitoring of botanic marks and rills. (a) Example of measured distance between the botanic mark and the actual topsoil (with $2 \mathrm{~cm}$ of the initial planting); (b) weekly geometrical rill monitoring: width and depth; (c) vintage: vine growers use rills to ascend or descend the vineyards; (d) imaginary polygon to calculate the soil loss with botanic marks.

\subsubsection{Geometrical rills monitoring}

Three rills with different geomorphological origins were chosen for the monitoring (R1, R2 and R3). The rills were divided into $1 \mathrm{~m}$ sections. Between September and December, the width, depth and slope angle of the sections along rills were measured. The first rill (R1) was caused by the wheel tracks and it was nearly $30 \mathrm{~m}$ long ( 30 sections), starting from the bottom of the embankment. The average inclination of the rill was $28^{\circ}$ and had approximately a contributing catchment area of $600 \mathrm{~m}^{2}$. The second (R2) and third (R3) rills were located on the embankments with steeper slopes (34 and $31.7^{\circ}$ ) and had smaller contributing catchment areas (19 and $25 \mathrm{~m}^{2}$ ). R2 (near a wall and drainage channel) was $7 \mathrm{~m}$ length (7 sections), and R3 was around $10 \mathrm{~m}$ (10 sections). Both were caused by the footsteps of vine workers. The methods of Govers and Poesen (1987), Takken et al. (1999), Vandekerckhove et al. (2003) and Wirtz et al. (2012) were followed to measure their changes in geometry. In order to calculate weekly the geometrical variation of transects, the geometrical channel cross-section index was calculated (Dingman, 2008; Quiquerez et al. 2008):

$\mathrm{TSI}=W / Y$,

where $W$ represents the width and $Y$ the depth (both in centimetres). Note that while the quotient is more elevated, the widening process of rills is faster than the deepening process. Furthermore, the standard deviation was added to distinguish when averages were obtained with equal or unequal values. Consequently, two types of analyses with the geometrical channel cross-section index (Dingman, 2008; Quiquerez et al., 2008) were elaborated. Inclination was measured with a clinometer in grates.

First, the total average values per section were used to detect the most vulnerable transects, which were mostly modified by geomorphological changes both temporally and spatially. The second calculation aimed to show the geometrical variation of each rill between the monitoring phases with the standard deviation (before, during and after vintage).

\subsubsection{Frontal botanic marks on the graft union}

The distance between frontal marks on the graft union and the visible actual rootstock of grape vines were measured (Fig. 3) on a total area of 0.065 ha (with old grapevines) and on 0.043 ha (with young grapevines). Graft union can be defined as unearthing or buried signal, which could show the theoretical ancient topsoil (Brenot et al., 2008). This analysis aims to confirm the theory about the "botanic marks" as indicators of soil loss (Brenot et al., 2008; Casalí et al., 2009; Paroissien et al., 2010). Vitis vinifera after the Phylloxera crisis was grafted with the American scion of controlled species as the Vitis rupestris, Vitis riparia and Vitis berlandieri (Unwin, 1996). Several authors (Brenot et al. 2008; Casalí et al., 2009; Paroissien et al., 2010) demonstrated that these signals were correct indicators of soil movements in the vineyards 
(erosion, transport and sedimentation). The conditions described in Brenot et al. (2008), previously confirmed with the vine growers, were as follows: (i) there is no vertical growth of the graft after the vineyard plantation; (ii) the recommendations concerning the graft union elevation at the vineyard are followed so that this elevation can be considered to be constant over the studied region; (iii) the measurement errors are negligible compared to the observed unearthing or burying of vine rootstock.

Furthermore, all graft unions near $2 \mathrm{~cm}$ from the topsoil were planted during the first year. In total 1200 graft unions were measured with a subtraction of $2 \mathrm{~cm}$, from which 720 were cultivated 35 years ago on the study area (coinciding with the monitored rills). The other 480 were planted in 2012. The average inclination of the hillslope is almost constant from 22 to $24^{\circ}$. It is important to note that a little contention wall with a drainage vertical collector (adjacent to R2) divides the study area in two parts. This infrastructure was planned to reduce accumulation of the eroded materials along the road and to drain the possible surface flow.

\subsection{Statistical and spatial analysis}

A continuation, which is two isoline maps of the present soil erosion level, was realized according to the geomorphological conditions of the plots. The co-kriging method (Dirks, 1998; Goovaerts, 1999; Wang et al., 2013) was applied with 0.1 precision intervals (quartiles) and two variables: botanic marks and digital elevation model with a resolution of $1 \times 1 \mathrm{~m}$.

The total soil loss was calculated from the volume of an imaginary polygon and then it was extrapolated to $\mathrm{m}^{3} \mathrm{ha}^{-1}$ and tha $\mathrm{yr}^{-1}$ with an estimation. The sides of the polygon were the distance between each vine stock $(0.9 \times 1 \mathrm{~m})$, while the height was the distance between the botanic marks on the graft union and the visible actual rootstock. Total soil loss $\left(\mathrm{tha}^{-1}\right)$ was estimated with the erosion-deposition (ER) equation (Paroissien et al., 2010):

$\mathrm{ER}=\frac{\mathrm{Vol} \times \mathrm{Ds}}{\mathrm{St} \times \mathrm{Av}}$.

The volume (Vol), the total area field (St), the age of the vines (Av) and the bulk density data (Ds) were applied. For the young vineyards $1.14 \mathrm{~g} \mathrm{~cm}^{3}$ was used and for the old vineyards $1.4 \mathrm{~g} \mathrm{~cm}^{3}$ was used, both the average of the two soil samples in different depth $(0-5$ and $5-15 \mathrm{~cm})$. At this level, this method also requires the assumption that the study area is absolutely even. However, due to the rills, footsteps and wheel tracks, it is actually rough.

\section{Results}

\subsection{Soil analysis}

Laboratory analysis data (Table 1) showed chemical and physical properties of the soils. The old (> 68\%) and young $(>70 \%)$ vineyards have the highest concentration of grain size larger than $2 \mathrm{~mm}$, which could be classified as stony soils. The highest concentration of organic matter (10-13\%) was noted on the surface horizon $(0-5 \mathrm{~cm})$ along the old vineyards and the upper embankment in accordance with the most elevate rates of bulk density $\left(1.4 \mathrm{~g} \mathrm{~cm}^{3}\right)$. The young vineyards and the below embankment have less organic matter $(<6 \%)$ and more fine sediment concentration $(<31 \%)$. The most elevated point of saturation and water absorption capacity of the soil samples were calculated along the subsurface horizons $(5-15 \mathrm{~cm})$.

The results of $K$ factor, indicating the erodibility of soil following Wischmeier and Smith (1978) and Dabney et al. (2014), showed 0.22 and 0.37 for old and young vineyards respectively. Finally, Cambisol leptic-humic was classified using these data with the methodology of FAO (IUSS Working Group WRB 2006, 2007, 2014).

\subsection{Rainfall events and land management during the study period}

Soil surface characteristics during and after the agricultural activity and the extrapolated rainfalls in 2013 (total and intensity) from the nearby climate stations were described to add more information (Table 2). The probability of the return period (Table 3) was added to include the recurrence of different rainfall depth and intensities per day. The precipitation between 20 and $5 \mathrm{~mm} \mathrm{~d}^{-1}$ and between 5 and $0.1 \mathrm{~mm} \mathrm{~d}^{-1}$ had the highest probability (36.1-36.3 and $22.6-23 \%$ respectively). The more intense rainfall events $\left(>40 \mathrm{~mm} \mathrm{~d}^{-1}\right)$ have the lowest possibility. The probability of rainfall events at this monitored season could be classified between 22.7 and $23 \%$.

Each week we could observe with the field work during the rill monitoring and with the meteorological data that since the vintage until 1 week after the recollection a powerful anthropic action was observed. The number of footsteps decreased 2 weeks after vintage, coinciding with the decreasing of rainfall depth $(51.4 \mathrm{~mm}$ in November to $7.96 \mathrm{~mm}$ in December) and intensity $\left(7.3 \mathrm{~mm} \mathrm{~d}^{-1}\right.$ to $\left.0.5 \mathrm{~mm} \mathrm{~d}^{-1}\right)$. Accordingly, less soil movement was observed and the rills began to widen. However, currently every morning the soil was frozen and along the day a thaw was occurred.

\subsection{Rainfall simulations}

Rainfall simulation experiments were carried out (Table 4), but only the summer simulations gave quantifiable result about runoff and soil loss (Fig. 4). During the other simulations, $100 \%$ infiltration rate was observed. 
Table 1. Soil analysis of the study area.

\begin{tabular}{|c|c|c|c|c|c|c|c|c|}
\hline Soil samples & $\begin{array}{l}>2 \mathrm{~mm} \\
(\% \text { Total })\end{array}$ & $\begin{array}{l}<2 \mathrm{~mm} \\
(\% \text { Total })\end{array}$ & $\mathrm{pH}$ & $\operatorname{TOC}(\%)^{\mathrm{a}}$ & $\operatorname{TIC}(\%)^{\mathrm{b}}$ & Saturation $(\%)^{\mathrm{c}}$ & $\begin{array}{l}\text { Absorption } \\
\text { capacity } \\
(\%)^{\mathrm{d}}\end{array}$ & $\begin{array}{l}\text { Bulk } \\
\text { density } \\
\left(\mathrm{gr} \mathrm{cm}^{3}\right)\end{array}$ \\
\hline $\begin{array}{l}\text { Old grapevines } \\
(0-5 \mathrm{~cm})\end{array}$ & 68.18 & 31.82 & $6.8 \pm 0.2$ & $10.7 \pm 0.2$ & $1.5 \pm 0.2$ & $11.3 \pm 0.8$ & $12.7 \pm 0.8$ & $1.4 \pm 0.4$ \\
\hline $\begin{array}{l}\text { Old grapevines } \\
(5-15 \mathrm{~cm})\end{array}$ & 66.19 & 33.81 & $6.8 \pm 0.2$ & $6.5 \pm 0.4$ & $1.5 \pm 0.4$ & $9.8 \pm 1.8$ & $10.9 \pm 0.08$ & $1.4 \pm 0.3$ \\
\hline $\begin{array}{l}\text { Upper embank- } \\
\text { ment } \\
(0-5 \mathrm{~cm})\end{array}$ & 61.45 & 38.55 & $6.6 \pm 0.07$ & $13.7 \pm 0.7$ & $1.5 \pm 0.2$ & $10.1 \pm 1.8$ & $11.2 \pm 2.2$ & $1.4 \pm 0.2$ \\
\hline $\begin{array}{l}\text { Upper embank- } \\
\text { ment } \\
(5-25 \mathrm{~cm})\end{array}$ & 58.25 & 41.75 & $6.9 \pm 0.7$ & $6.6 \pm 0.8$ & $2.2 \pm 0.9$ & $11.2 \pm 2.3$ & $12.6 \pm 3$ & $1.4 \pm 0.4$ \\
\hline $\begin{array}{l}\text { Below embank- } \\
\text { ment } \\
(0-5 \mathrm{~cm})\end{array}$ & 61.82 & 38.18 & $6.6 \pm 0.2$ & $5.7 \pm 0.03$ & $1.3 \pm 0.01$ & $9.1 \pm 0.7$ & $10 \pm 0.8$ & $1.3 \pm 0.2$ \\
\hline $\begin{array}{l}\text { Below embank- } \\
\text { ment } \\
(5-25 \mathrm{~cm})\end{array}$ & 68.85 & 31.15 & $6.6 \pm 0.2$ & $5.7 \pm 0.01$ & $1.4 \pm 0.1$ & $11.8 \pm 0.07$ & $13.4 \pm 0.08$ & $1.4 \pm 0.1$ \\
\hline $\begin{array}{l}\text { Young grapevines } \\
(0-5 \mathrm{~cm})\end{array}$ & 70.17 & 29.83 & $6.8 \pm 0.2$ & $4.1 \pm 0.4$ & $2.3 \pm 0.3$ & $11 \pm 5.3$ & $12.5 \pm 6.7$ & $1.1 \pm 0.8$ \\
\hline $\begin{array}{l}\text { Young grapevines } \\
(5-25 \mathrm{~cm})\end{array}$ & 70.68 & 29.32 & $6.5 \pm 0.5$ & $5.5 \pm 0.3$ & $1.5 \pm 0.3$ & $12.7 \pm 0.06$ & $14.5 \pm 0.07$ & $1.2 \pm 0.1$ \\
\hline
\end{tabular}

(a) TOC is total organic carbon; (b) TIC is total inorganic carbon; (c) saturation $(\%)=($ water added to saturation/final weight $) \times 100$; $(\mathrm{d})$ absorption capacity $(\%)=($ weight of saturated aggregate - initial weight/initial weight $\times 100$.

Table 2. Rainfall events and agricultural activities descriptions during the monitoring.

\begin{tabular}{|c|c|c|c|c|c|}
\hline $\begin{array}{l}\text { Monitoring } \\
\text { phase }\end{array}$ & Date & $\begin{array}{l}\text { Rainfall } \\
(\mathrm{mm})^{\mathrm{a}}\end{array}$ & $\begin{array}{l}\text { Days } \\
\text { with rain }\end{array}$ & $\begin{array}{l}\text { Intensity } \\
\left(\mathrm{mmd}^{-1}\right)\end{array}$ & Activities \\
\hline \multirow{3}{*}{$\begin{array}{l}\text { Before } \\
\text { vintage }\end{array}$} & 24 Sep 2013 & 22.98 & 6.6 & 3.3 & \multirow{3}{*}{$\begin{array}{l}\text { Leaves of the grapevines were cut to improve } \\
\text { the absorption of the sunlight and appearance of } \\
\text { footsteps. }\end{array}$} \\
\hline & 01 Oct 2013 & 10.34 & 4.3 & 1.5 & \\
\hline & 08 Oct 2013 & 1.25 & 2.5 & 0.2 & \\
\hline \multirow[t]{5}{*}{ Vintage } & 15 Oct 2013 & 22.78 & 3.3 & 3.3 & \multirow{3}{*}{$\begin{array}{l}\text { Several footsteps marks were situated from the sec- } \\
\text { tions } 0-1 \text { to } 8-9 \mathrm{~m} \text {. Many grapes and leaves stayed } \\
\text { on the surface. }\end{array}$} \\
\hline & 22 Oct 2013 & 26.63 & 4.1 & 3.8 & \\
\hline & 29 Oct 2013 & 8.78 & 4.9 & 1.3 & \\
\hline & 06 Nov 2013 & 51.40 & 5.9 & 7.3 & $\begin{array}{l}\text { Several footsteps modified R2. It increased lateral } \\
\text { enlargement (no deepening). }\end{array}$ \\
\hline & 12 Nov 2013 & 33.96 & 4.5 & 4.9 & $\begin{array}{l}\text { Many grape leaves and branches on the surface. } \\
\text { Footsteps began to dissolve on monitored rills (1, } \\
2 \text { and 3). }\end{array}$ \\
\hline \multirow[t]{4}{*}{$\begin{array}{l}\text { After } \\
\text { vintage }\end{array}$} & 19 Nov 2013 & 10.34 & 6.3 & 1.5 & $\begin{array}{l}\text { The soil was cleaned from leaves and branches. } \\
\text { Footsteps formed new rills through rainfall. }\end{array}$ \\
\hline & 26 Nov 2013 & 1.95 & 4.0 & 0.3 & \multirow{2}{*}{$\begin{array}{l}\text { Each morning soil freeze appeared. After midday } \\
\text { the soil was almost dry, but the subsurface horizons } \\
\text { were not. }\end{array}$} \\
\hline & 03 Dec 2013 & 7.96 & 4.8 & 1.1 & \\
\hline & 10 Dec 2013 & 3.24 & 4.3 & 0.5 & $\begin{array}{l}\text { Footsteps marks were visible only from the sec- } \\
\text { tions } 0-1 \text { to } 1-2 \text {. Rills stayed without remarkable } \\
\text { changes. }\end{array}$ \\
\hline
\end{tabular}

${ }^{\text {a }}$ Rainfall (mm) means total millimetres after each measure, currently, each 6 or 7 days. 
Table 3. Return period of rainfall events per year.

\begin{tabular}{ll}
\hline $\begin{array}{l}\text { Rainfall depth } \\
(\mathrm{mm})\end{array}$ & $\begin{array}{l}\text { \% probability of return } \\
\text { period }\left(\mathrm{d}^{-1} \mathrm{yr}^{-1}\right)\end{array}$ \\
\hline$>40$ & $0.44-0.46$ \\
$40-20$ & $5.65-7.23$ \\
$20-5$ & $36.12-36.36$ \\
$5-0.1$ & $22.67-22.95$ \\
0 & $9.02-11.16$ \\
\hline
\end{tabular}

For the four simulations of August, runoff and sediment suspension data appeared. The maximum runoff coefficient and suspended sediment load were $15.2 \pm 7.8 \%$ and $25.81 \mathrm{~g} \mathrm{~m}^{-2}$ respectively. These values were lower compared to the infiltration averages (near $100 \%$ ). In each experiment, only one increase interval of soil loss and at the same time more surface runoff was noted. Consequently, the sediment concentration decreased. Principally, this situation happened in the central minutes of the rainfall simulation (between 10 and $20 \mathrm{~min}$ ), when the soil became saturated and expelled water as surface flow. After this saturation point, the A horizon was being eliminated and it seemed that the water could be moving as subsurface flow by gravity.

Finally, for the last simulation in December, a soil profile of $0.5 \mathrm{~m}$ below the simulator was excavated (Fig. 2) in order to observe the intensity and direction of a possible subsurface flow. From the beginning of the simulation, this hydrodynamic behaviour of total infiltration was noted across the profile. However, we could not calculate the intensity and observe the direction in situ, because the water flowed across an area larger than the rainfall simulator collector.

\subsection{Geometrical monitoring of rills with anthropic origin}

Size variations of the rills are presented in graphics with data from the monitoring period (Figs. 5 and 6).

The highest variations were observed before and during vintage. In general, using the geometrical channel crosssection index, four intervals were detected with relevant weekly changes for all rills: (i) between $0-1$ and 1-2 m (below the hillslope), irregularities were noted in little alluvial fans on the border of the embankment and the road; (ii) from 3-4 to 4-5 m fractures appeared in the slope as a microterrace (between 32 and $36^{\circ}$ of slope), in which small slide scars by the soil movements were noticed below the A horizon; (iii) along 7 and $9 \mathrm{~m}$ at the top of the embankment, where the vines grapes were cultivated (the slopes were 30 to $23^{\circ}$ ); (iv) for R1 only (originated by wheel tracks), an increase of the values of geometrical cross-section index from 26 to $27 \mathrm{~m}$ and a maintaining of the gradient $\left(27-28^{\circ}\right)$ were seen. In this section, weeding was favoured as opposed to the deepening process, especially during the vintage. Moreover,
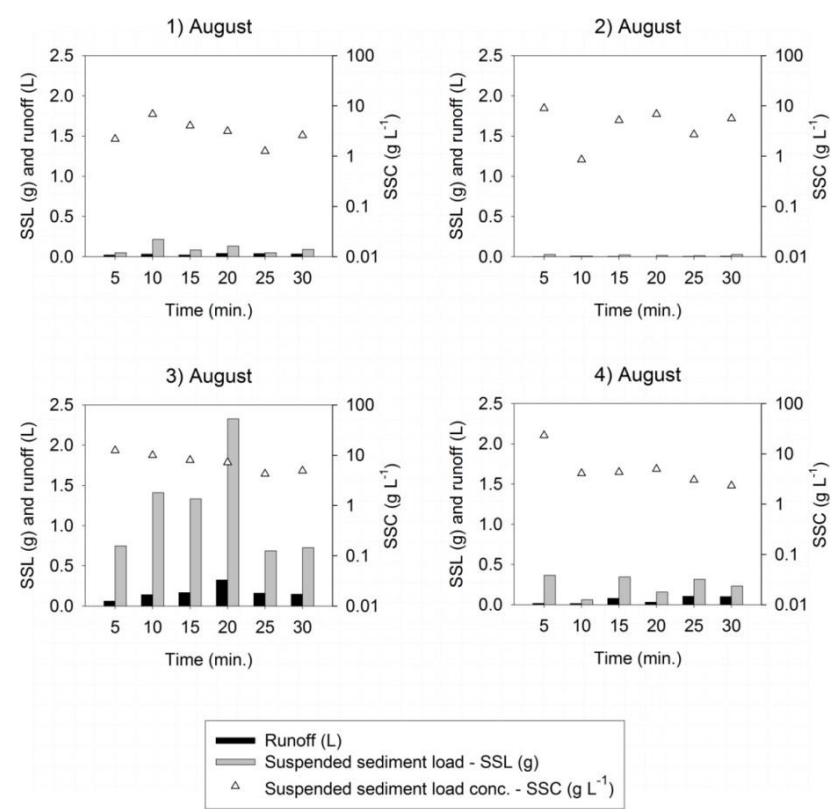

Figure 4. Relationships between variables: surface flow, suspension and sediment concentration.
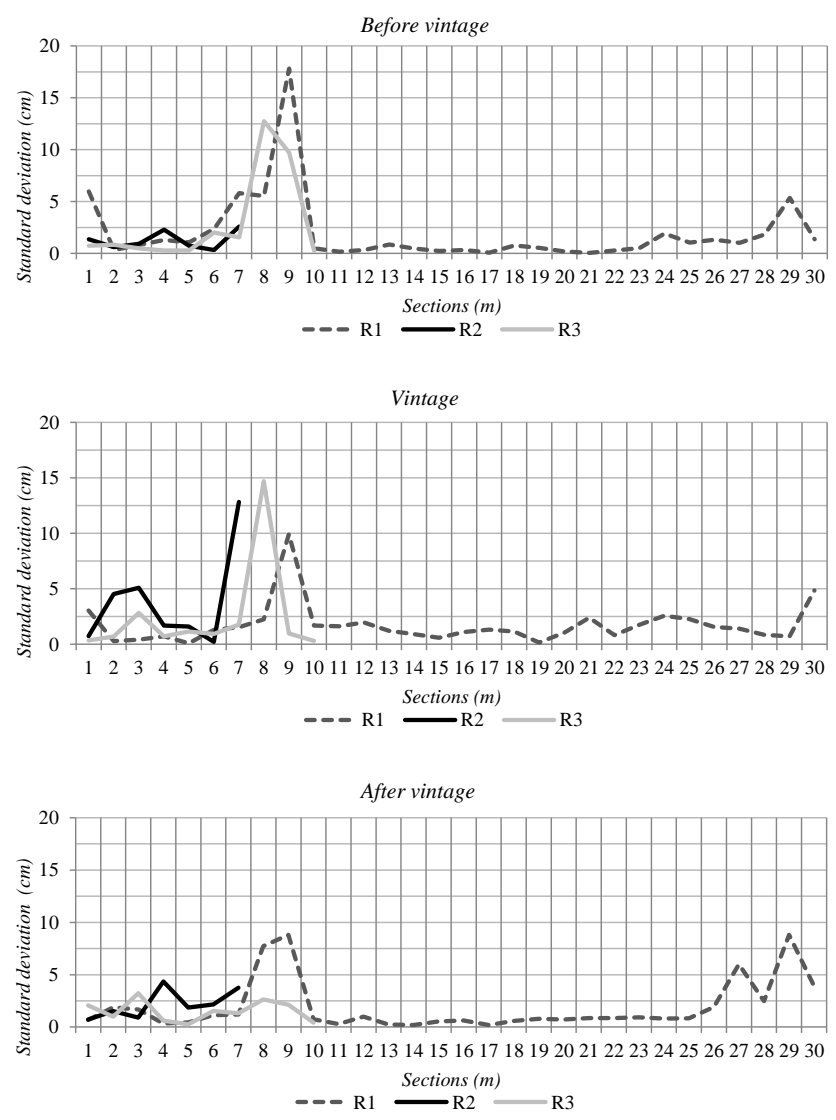

Figure 5. Temporal and spatial development of the monitored rills (R1, R2 and R3). 
Table 4. Rainfall simulation parameters.

\begin{tabular}{lcccccc}
\hline ID & $\begin{array}{c}\mathrm{Pp} \\
\left(\mathrm{mm} \mathrm{h}^{-1}\right)\end{array}$ & $\begin{array}{c}\text { Runoff } \\
(\mathrm{L} / 5 \mathrm{~min})\end{array}$ & $\begin{array}{c}\text { Runoff coef./ } \\
5 \mathrm{~min}(\%)\end{array}$ & $\begin{array}{c}\text { Infiltration/ } \\
5 \mathrm{~min}(\%)\end{array}$ & $\begin{array}{c}\text { Concentration/ } \\
5 \mathrm{~min}\left(\mathrm{gL}^{-1}\right)\end{array}$ & $\begin{array}{c}\text { Total erosion } \\
\left(\mathrm{g} \mathrm{m}^{-2} \mathrm{~h}^{-1}\right)\end{array}$ \\
\hline 01 Aug 2012 & 9.72 & $0.03 \pm 0.01$ & $3.9 \pm 1.1$ & $96.1 \pm 1.1$ & $3.34 \pm 1.95$ & 23.2 \\
02 Aug 2012 & 10.32 & $0.004 \pm 0.002$ & $0.52 \pm 0.2$ & $99.5 \pm 0.2$ & $5.03 \pm 2.91$ & 30.9 \\
03 Aug 2012 & 13.2 & $0.17 \pm 0.09$ & $15.2 \pm 7.8$ & $84.8 \pm 7.8$ & $7.77 \pm 3.07$ & 51.5 \\
04 Aug 2012 & 10.44 & $0.06 \pm 0.04$ & $6.7 \pm 4.8$ & $93.3 \pm 4.8$ & $7.01 \pm 8.03$ & 30.5 \\
05 Oct 2013 & 10.8 & 0 & 0 & 100 & 0 & 0 \\
06 Oct 2013 & 10.68 & 0 & 0 & 100 & 0 & 0 \\
07 Nov 2013 & 11.16 & 0 & 0 & 100 & 0 & 0 \\
08 Dec 2013 & 9.48 & 0 & 0 & 100 & 0 & 0 \\
\hline
\end{tabular}

a Rainfall simulation without A horizon.
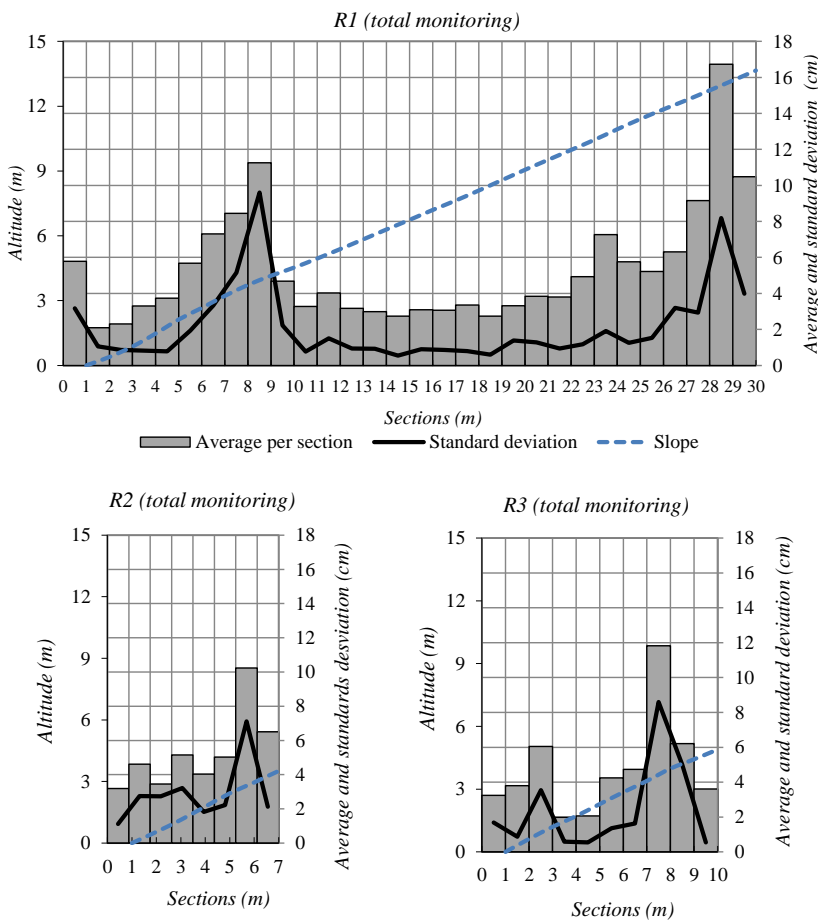

Figure 6. Geometrical channel cross-section developments of the rills during the whole monitoring period (R1, R2 and R3).

average values (Figs. 7 and 8) in each rill with this index were noted.

For R2 (significantly modified by several footsteps), a higher value $(5.3 \pm 2.9 \mathrm{~cm})$ was obtained than for $\mathrm{R} 3$ $(4.9 \pm 2.5 \mathrm{~cm})$.

At R1 $(5.3 \pm 2.2 \mathrm{~cm})$ between 1 and $10 \mathrm{~m}$, elevated data were observed $(5.5 \pm 2.9 \mathrm{~cm})$, but from here the values were descending $(5.3 \pm 1.8 \mathrm{~cm})$. Finally, the highest parameters were measured from $27 \mathrm{~m}(10.7 \pm 4.6 \mathrm{~cm})$, during the weeding processes (confluence of two or more rills).

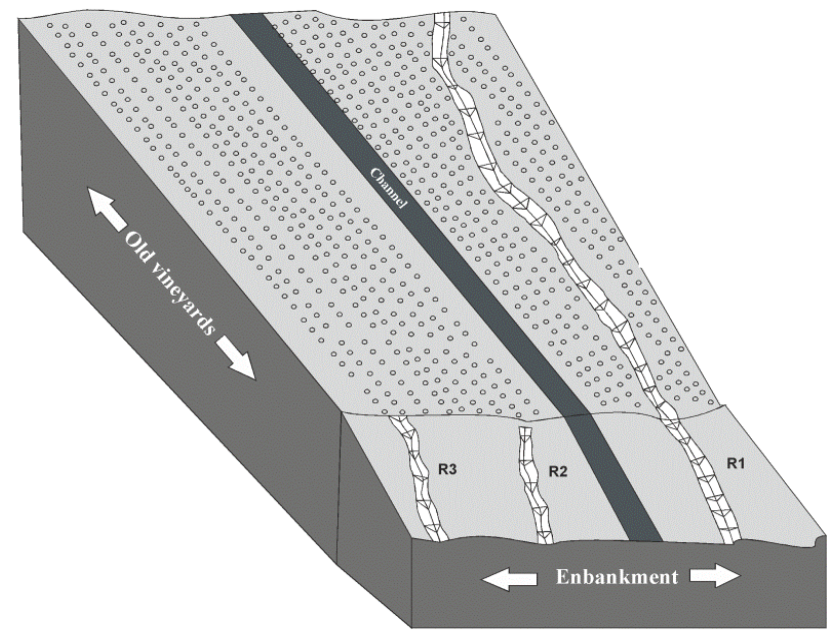

Figure 7. Diagram of the embankment with the rills on the old vineyards.

\subsection{Soil loss level maps}

Figures 9 and 10 present the soil losses and the trend of movements. Annual average soil loss per row, on each side of the contention wall and on the total study area is shown on the Table 5.

At each side of the channel and the contention wall at both vineyards, diverse dynamics were observed. The highest erosion rates (dark colours) were located on the top at the left side of the hillslope. This situation was increased near the channel in contact with the embankment on the left side (for the young grapevines 134.1 and $124.3 \mathrm{tha}^{-1}$ in the old vineyard). The behaviour is more in accordance with the natural conditions on the right side, because the soil loss was lower (light colours) and below the accumulation was predominant (in 2 years it was $116 \mathrm{tha}^{-1}$ and in 35 years it was 113 tha $^{-1}$ ).

In 2 years of cultivation, very high total soil loss was calculated (125 and $62.5 \mathrm{tha}^{-1} \mathrm{yr}^{-1}$ ). However, for the old vineyards (35 years), $118.7 \mathrm{tha}^{-1}$ erosion rates with an an- 

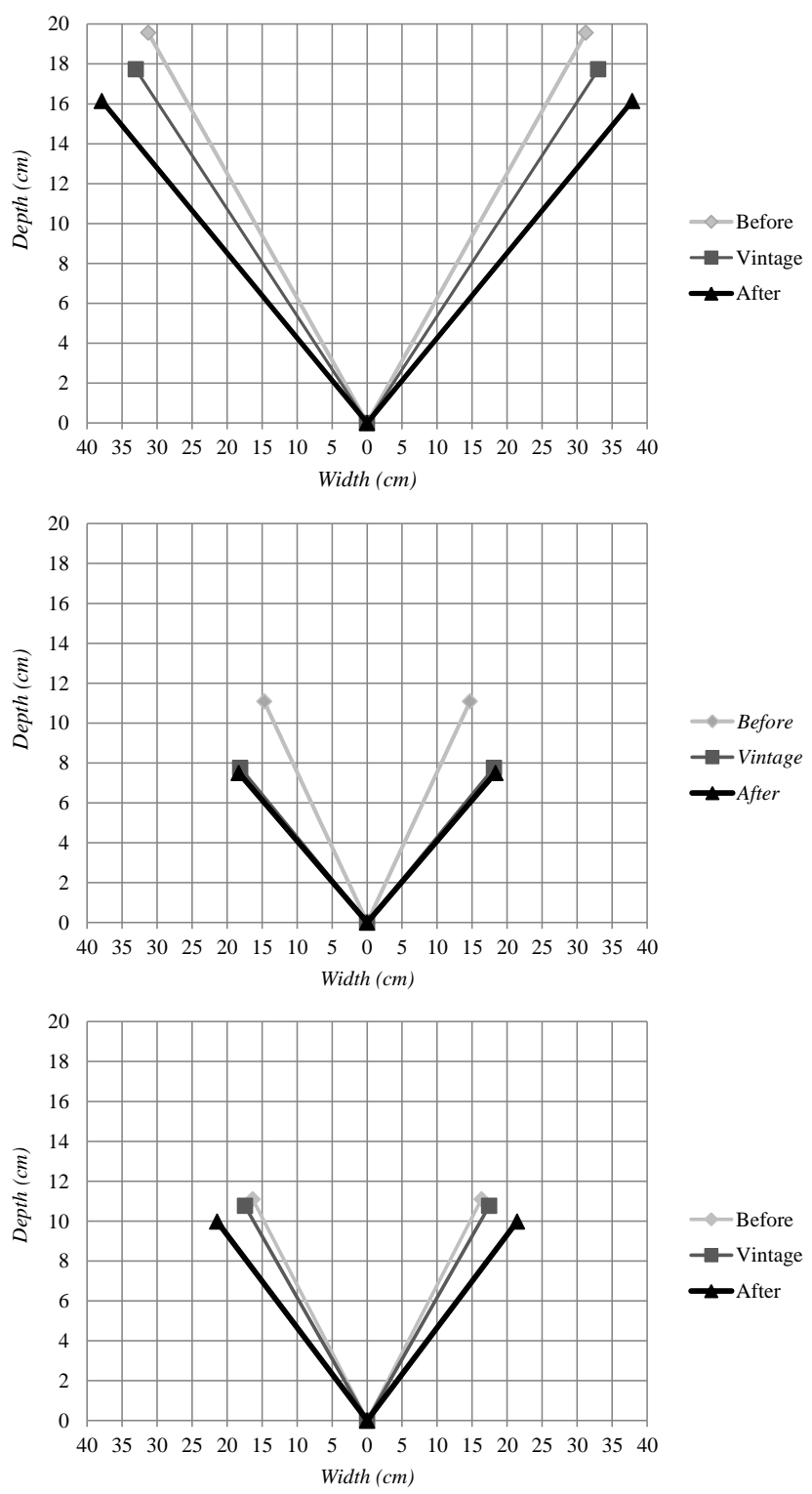

Figure 8. Geometrical channel cross-section averages of the rills during the total monitoring period (R1, R2 and R3) on the old vineyards.

nual rate of $3.4 \mathrm{tha}^{-1} \mathrm{yr}^{-1}$ was calculated. Again, on the left side losses were higher than on the right side (3.6 and $\left.3.2 \mathrm{tha}^{-1} \mathrm{yr}^{-1}\right)$.

\section{Discussion}

During this study, the application of different tools and experiments on the soil led to the following observations: (i) subsurface processes, such as micro-piping or creeping, and (ii) concrete pedological conditions, like variations between agricultural seasons or geomorphological instability after soil tilling.
Due to the stony soil surface (between 58.3 and $70.7 \%$ larger soil particles than $2 \mathrm{~mm}$ ) and the active cultivation work (wheel tracks and footsteps along the inter-rows), high infiltration rates (near $100 \%$ ) and high soil loss rates were observed. The highest organic matter content and bulk density were noted in the old vineyards, which could explain a lower sediment transport or soil movements across the hillslope than at the young vineyards and the embankments. However, the most saturation and absorption capacity rates were located from $5 \mathrm{~cm}$ depth. Subsurface flow dynamics could be analyzed, maybe according a high porosity rates due to these stony soils.

Spatial and temporal geometrical evolutions of rills were monitored with the geometrical channel cross-section index before, during and after the agricultural activities (vintage) in the study area. Accordingly, soils had three different responses in the three different situations. The highest variability (width and depth) of the rills was observed on the embankment close to the contention wall and drainage channel. These increases were developed by (i) soil tilling (land removal), (ii) any roots that could hold the soil and (iii) one uncorrected located wall. The footsteps and wheel tracks before and during vintage increased the dynamic of these processes. This was coinciding with the frequent and intensive rainfall events.

The impact of land management was evaluated with the total soil losses rates using the botanic marks of the grapes. However, an elevate component of subjectivity is adverted by several authors, because the method depends on arbitrary criteria. With this method, $118.7 \mathrm{tha}^{-1}$ soil loss was calculated in the old vineyard, which means $3.4 \mathrm{tha}^{-1} \mathrm{yr}^{-1}$. Respectively in the young vineyard $125 \mathrm{tha}^{-1}$, which supposes $62.5 \mathrm{tha}^{-1} \mathrm{yr}^{-1}$, were measured. During the first years of plantation, very high rates of soil losses was observed. However, the next years the sediment transport descends considerably due possibly to (i) the soil tillage against the erosion increasing or (ii) the structural stability of soils improving continuously since the plantation (organic matter, bulk density, absorption capacity, etc.). It might be important to know how much money the vine growers could save before directly correcting land management measures on the hillslopes. Territories with intensive and mountain farming should be considered vulnerable to erosion problems. Policies must aim to protect hillslope morphologies for terracing and to prohibit indiscriminate heavy machinery use. Alterations can implicate changes with unappreciable consequences in the short term but that are irreversible in the long term (Piccarreta et al., 2006).

Finally, the erosion rates could be compared with other studies about vineyards in the Mosel Valley, Germany and Europe by different authors (Table 6). The problem is nowadays relevant.

As this study, Richter $(1975,1991)$ and Hacisalihoglu (2007) worked also in the Ruwer Valley vineyards but with different methodologies. In their experiments, they used sedi- 


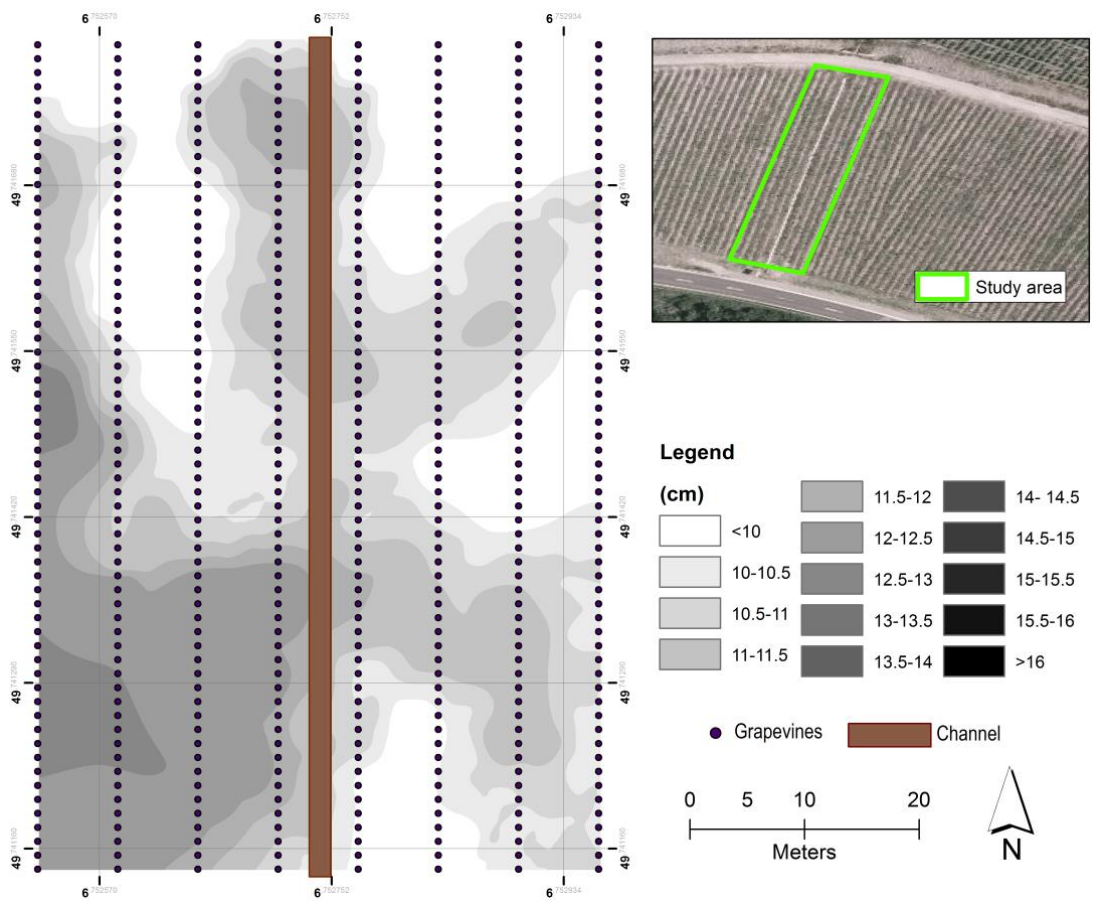

Figure 9. Soil level map of the young vineyard.

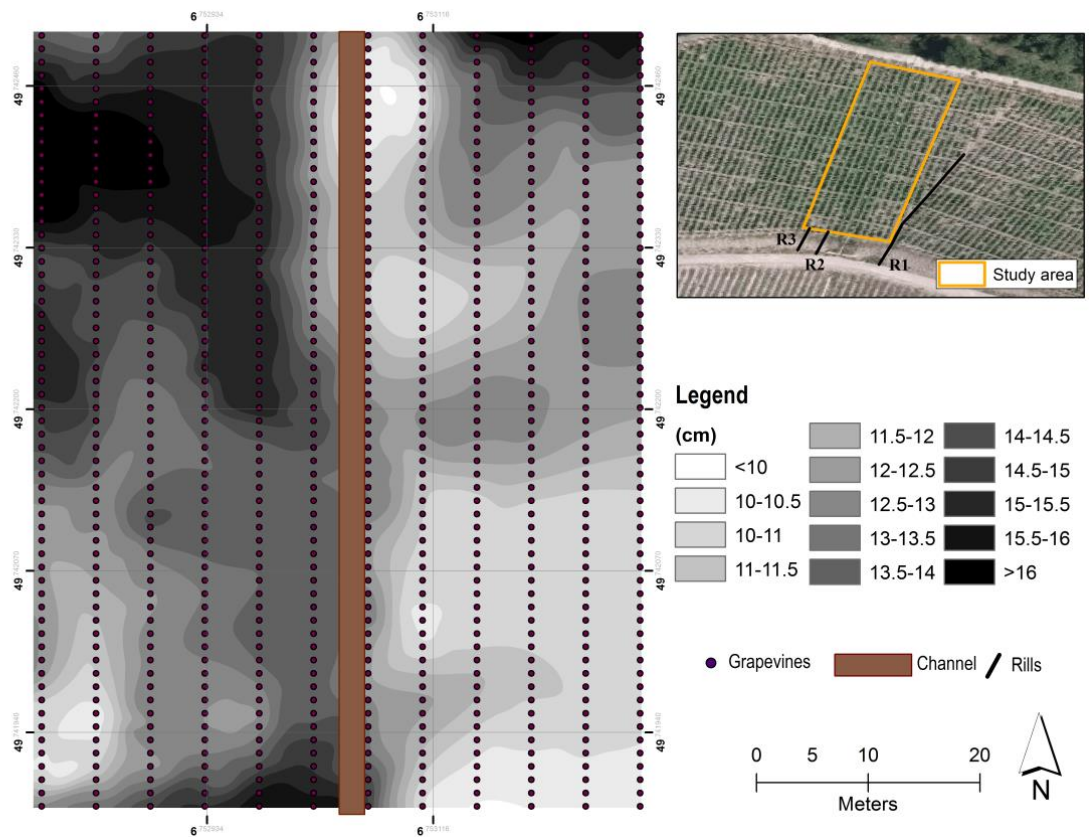

Figure 10. Soil level map of the old vineyard.

ment boxes and empiric equations, but the measured soil loss rates were similar to the erosion rates of the old vineyards of this paper $\left(3.4 \mathrm{tha}^{-1} \mathrm{yr}^{-1}\right)$ : 0.2-6.6 and $6.47 \mathrm{tha}^{-1} \mathrm{yr}^{-1}$ respectively. For other scales (Germany and Europe), Auerswald et al. (2009) and Cerdan et al. (2006, 2010) calculated similar soil erosion rates as well (5.2 and $\left.12.2 \mathrm{tha}^{-1} \mathrm{yr}^{-1}\right)$, with extrapolations from different works.

Only Emde (1992) with USLE inferred a rate over $150 \mathrm{tha}^{-1} \mathrm{yr}^{-1}$, which is approximated to the soil erosion of the young grapevines $\left(62.5 \mathrm{tha}^{-1} \mathrm{yr}^{-1}\right)$ in this paper. 
Table 5. Volume estimations of soil loss in young and old vineyards.

\begin{tabular}{|c|c|c|c|c|}
\hline & Parameters & $\mathrm{m}^{3}$ & $\mathrm{tha}^{-1 \mathrm{a}}$ & $\mathrm{tha}^{-1} \mathrm{yr}^{-1}$ \\
\hline \multirow[t]{3}{*}{ Young vineyards (2 years) } & Total soil loss & 4.7 & 125 & 62.5 \\
\hline & Total on the left side & 5.1 & 134.1 & 67.1 \\
\hline & Total on the right side & 4.4 & 116 & 58 \\
\hline \multirow[t]{3}{*}{ Old vineyards (35 years) } & Total soil loss & 5.5 & 118.7 & 3.4 \\
\hline & Total on the left side & 5.8 & 124.3 & 3.6 \\
\hline & Total on the right side & 5.2 & 113 & 3.2 \\
\hline
\end{tabular}

${ }^{a}$ tha ${ }^{-1}$ : the soil loss is equivalent to the total erosion since the first moment of plantation.

Table 6. Comparison of soil losses rates among different uses, territories and methodologies.

\begin{tabular}{|c|c|c|c|c|}
\hline Authors & Study area & Method & $\begin{array}{l}\text { Rates } \\
\left(\text { tha }^{-1} \mathrm{yr}^{-1}\right)\end{array}$ & Types of land uses \\
\hline $\begin{array}{l}\text { Richter } \\
(1975,1991)\end{array}$ & $\begin{array}{l}\text { Mertesdorf (Mosel } \\
\text { Valley) }\end{array}$ & Sediment boxes & $0.2-6.6$ & Vineyards \\
\hline Emde (1992) & $\begin{array}{l}\text { Rheingau } \\
\text { (Rhin Valley) }\end{array}$ & USLE & 151 & Vineyards \\
\hline Hacisalihoglu (2007) & $\begin{array}{l}\text { Mertesdorf (Mosel } \\
\text { Valley) }\end{array}$ & $\begin{array}{l}\text { "Allgemeine } \\
\text { Bodenabtragsgle- } \\
\text { ichung" (ABAG) }\end{array}$ & $\begin{array}{l}0.71 \\
0.67 \\
0.87 \\
1.2 \\
6.47\end{array}$ & $\begin{array}{l}\text { Regeneration } \\
\text { Forest } \\
\text { Shrubs } \\
\text { Grassland } \\
\text { Vineyards }\end{array}$ \\
\hline $\begin{array}{l}\text { Auerswald et al. } \\
(2009)\end{array}$ & Germany & $\begin{array}{l}\text { Extrapolations and } \\
R \text { factor of USLE } \\
\text { (Universal Soil } \\
\text { Loss Equation) }\end{array}$ & $\begin{array}{l}5.7 \\
0.5 \\
0.2 \\
5.2\end{array}$ & $\begin{array}{l}\text { Annual arable land } \\
\text { Grassland } \\
\text { Forest } \\
\text { Vineyards }\end{array}$ \\
\hline $\begin{array}{l}\text { Cerdan et al. (2006, } \\
2010)\end{array}$ & Europe & $\begin{array}{l}\text { Extrapolations } \\
\text { from other works }\end{array}$ & 12.2 & Vineyards \\
\hline This study & $\begin{array}{l}\text { Waldrach (Mosel } \\
\text { Valley) }\end{array}$ & Botanic marks & $3.4-62.5^{\mathrm{a}}$ & Vineyards \\
\hline
\end{tabular}

a $3.4 \mathrm{tha}^{-1} \mathrm{yr}^{-1}$ for the old vineyards (average in 35 years) and $62.5 \mathrm{tha}^{-1} \mathrm{yr}^{-1}$ for the other area with young grapevines (since 2012).

The results of this paper contribute to the validity of the available data, although the comparability with other studies is difficult due to the different methodological approaches and the diverse climatic situations. Furthermore, all studies coincided in the same assumption: the vineyards soil erosion rates were the highest compared to other land uses (forest, grassland, shrubs or regeneration).

\section{Conclusions}

Nowadays, the impact of human activities and incorrect land use management in vineyards generate high soil erosion rates and rill problems. The vineyards of Ruwer Valley (Germany) on steep slopes are one of these conditioned ecogeomorphological systems.
This study showed during different seasons (SeptemberDecember) and under different management conditions (before, during and after vintage): (i) high infiltration rates (near $100 \%$ ) and subsurface flow, using rainfall simulations carried out at different times of the year (SeptemberDecember); (ii) several lateral and frontal variations of rills before and during the vintage (September-October), coinciding with the increase in the footsteps of the vine growers; and (iii) using botanic marks on the graft union of the vines, indicating $62.5 \mathrm{tha}^{-1} \mathrm{yr}^{-1}$ soil loss rate in the new vineyards (2 years) and $3.4 \mathrm{tha}^{-1} \mathrm{yr}^{-1}$ on the old vineyards (35 years).

Acknowledgements. We acknowledge the Weinbauverband Moseland the winery Gebrüder Steffes (Waldrach) and the winery Langguth (Traben-Trarbach) for providing access to the study area. 
We also thank the CaixaBank and German Academic Exchange Service (Deutscher Akademischer Austauschdienst, DAAD) for the scholarship grant awarded to Jesús Rodrigo Comino.

Edited by: P. Pereira

\section{References}

Arnáez J., Lasanta, T., Ruiz-Flaño P., and Ortigosa, L.: Factors affecting runoff and erosion under simulated rainfall in Mediterranean vineyards, Soil Till. Res., 93, 324-334, doi:10.1016/j.still.2006.05.013, 2007.

Arnáez, J., Ruiz-Flaño, P., Lasanta, T., Ortigosa, L., Llorente, J. A., Pascual, N., and Lana-Renault, N.: Efectos de las rodadas de tractores en la escorrentía y erosión del suelo en laderas cultivadas con viñedos, Cuadernos de Investigación Geográfica, 38, 115130, 2012.

Ashenfelter, O. and Storchmann, K.: Using hedonic models of solar radiation and weather to assess the economic effect of climate change: the case of Mosel Valley vineyards, Rev. Econ. Stat., 92, 333-349, doi:10.1162/rest.2010.11377, 2010.

Auerswald, K., Fiener, P., and Dikau, R.: Rates of sheet and rill erosion in Germany (a meta-analysis). Geomorphology, 11, 182193, doi:10.1016/j.geomorph.2009.04.018, 2009.

Boardman, J., Poesen, J., and Evans, R.: Socio-economic factors in soil erosion and conservation, Environ. Sci. Policy, 6, 1-6, 2003.

Brandt, J. C. and Thornes, J. B.: Mediterranean Desertification and Land Use, Wiley, Chichester, UK, 1996.

Brenot, J., Quiquerez, A., Petit, C., and Garcia, J. P.: Erosion rates and sediment budgets in vineyards at $1-\mathrm{m}$ resolution based on stock unearthing (Burgundy, France), Geomorphology, 100, 345-355, doi:10.1016/j.geomorph.2008.01.005, 2008.

Bryan, R. B.: Soil erodibility and processes of water erosion on hillslope, Geomorphology, 32, 385-415, doi:10.1007/BF02872682, 2000.

Casalí, J., Giménez R., De Santisteban, L., Álvarez-Mozos, J., Mena, J., and Del Valle de Lersundi, J.: Determination of long-term erosion rates in vineyards of Navarre (Spain) using botanical benchmarks, Catena, 78, 12-19, doi:10.1016/j.catena.2009.02.015, 2009.

Casper, M., Grigoryan, G., Heinemann, G., and Bierl, R.: Auswirkungen des Klimawandels auf die Ressource Wasser in Rheinland-Pfalz - Rheinland-Pfalz Kompetenz-Zentrum für Klimawandelfolgen, in: Schlussberichte des Landesprojekts Klima und Landschaftswandel in Rheinland-Pfalz (KlimLandRP), 2, Wasser Modul, Trier, Germany, 2013.

Cerdà, A., Ibáñez, S., and Calvo, A.: Design and operation of a small and portable rainfall simulator for rugged terrain, Soil Technol., 11,, 163-170, 1997.

Cerdan, O., Poesen, J., Govers, G., Saby, N., Le Bissonnais, Y., Gobin, A., Vacca, A., Quinton, J., Auerswald, K., Klik, A., Kwaad, F. F. P. M., and Roxo, M. J.: Sheet and rill erosion, in: Soil Erosion in Europe, edited by: Boardman, J., Poesen, J., John Wiley and Sons, Chichester, UK, 501-513, doi:10.1002/0470859202.ch38, 2006.
Cerdan, O., Govers, G., Le Bissonnais, Y., Van Oost, K., Poesen, J., Saby, N., Gobin, A., Vacca, A., Quinton, J., Auerswald, K., Klik, A., Kwaad, F. J. P. M., Raclot, D., Ionita, I., Rejman, J., Rousseva, S., Muxart, T., Roxo, M. J., and Dostal, T.: Rates and spatial variations of soil erosion in Europe: a study based on erosion plot data, Geomorphology, 122, 167-177, doi:10.1016/j.geomorph.2010.06.011, 2010.

Corbane, C., Andrieux, P., Voltz, M., Chadaeuf, J., Albergel, J., Robbez-Masson, J. M., and Zante, P.: Assessing the variability of soil surface characteristics in row-cropped fields: the case of Mediterranean vineyards in Southern France, Catena, 72, 79-90, doi:10.1016/j.catena.2007.04.006, 2008.

Dabney, S. M., Yoder, D. C., and Vieira, D. A. N.: The Application of the Revised Universal Soil Loss Equation, Version 2, to evaluate the impacts of alternative climate change scenarios on runoff and sediment yield, J. Soil Water Conserv., 67, 343-353, 2012.

Davies, B.: Loss-on ignition as an estimate of soil organic matter, Soil Sci. Proc., 38, 150, 1974.

Dent, D. and Young, A.: Soil Survey and Land Evaluation, George Allen and Unwin, London, 1981.

Deutscher Wetterdienst (DWD), available at: http://www.dwd.de/.

Dienstleistungszentren Ländlicher Raum-Rheinland-Pfalz (DLRRLP), available at: ttp://www.dlr.rlp.de.

Dingman, S. L.: Fluvial Hydraulics, Oxford Press University, New York, USA, 2008.

Dirks, K. N., Hay, J. E., Stow, C. D., and Harris, D.: High-resolution studies of rainfall on Norfolk Island Part II: interpolation of rainfall data, J. Hydrol., 208, 187-193, 1998.

Eggenberger, W., Koblet, W., Mischler, M., Schwarzenbach, H., and Simon, J. L.: Weinbau, Landwirtschaftliche Lehrmittelzentrale, Zollikofen, 1990.

Emde, K.: Experimentelle Untersuchungen zu Oberflächenabfluß und Bodenaustrag in Verbindung mit Starkregen bei verschiedenen Bewirtschaftungssystemen in Weinbergsarealen des oberen Rheingaus, Geisenheimer Berichte, Vol. 12, Gesellschaft zur Förderung der Forschungsanstalt Geisenheim, Geisenheim, Germany, 1992.

Emerson, W. W.: A classification of soil aggregates based on their coherence in water, Austr. J. Soil Res. 5, 47-57, 1967.

Fox, D. M. and Bryan, R. B.: The relationship of soil loss by interrill erosion to slope gradient, Catena, 38, 211-222, doi:10.1016/S0341-8162(99)00072-7, 2000.

Goovaerts, P.: Geostatistics in soil science. State-of-the-art and perspectives, Geoderma, 89, 1-45, doi:10.1016/S00167061(98)00078-0, 1999.

Govers, G. and Poesen, J.: Assessment of the interrill and rill contributions to total soil loss from an upland field plot, Geomorphology, 1, 343-354, doi:10.1016/0169-555X(88)90006-2, 1987.

Hacisalihoglu, S.: Determination of soil erosion in a steep hill slope with different land-use types: a case study in Mertesdorf (Ruwertal/Germany), J. Environ. Biol., 28, 433-438, 2007.

Herrick, J.E., Whitford, W.G., De Soyza, A.G., Van Zee, J.W., Havstad, K.M., Seybold, C.A., Walton, M.: Field soil aggregate stability kit for soil quality and rangeland health evaluations, Catena 44, 27-35, 2001.

Herrick, J. E., Van Zee, J. W., Belnap, J., and Remmenga, M.: Fine gravel controls hydrologic and erodibility responses to trampling disturbance for coarse-textured soils with weak cyanobacterial 
crusts, Catena, 83, 119-126, doi:10.1016/j.catena.2010.08.007, 2010.

Imeson, A. C. and Vis, M.: Assessing soil aggregate stability by water-drop impact and ultrasonic dispersion, Geoderma, 34, 185-200, 1984.

Iserloh, T., Fister, W., Seeger, M., Willger, H., and Ries, J. B.: A small portable rainfall simulator for reproducible experiments on soil erosion, Soil Till. Res., 124, 131-137, doi:10.1016/j.still.2012.05.016, 2012.

Iserloh, T., Ries, J. B., Arnáez, J., Boix-Fayos, C., Butzen, V., Cerdà, A., Echeverría, M. T., Fernández-Gálvez, J., Fister, W., Geißler, C., Gómez, J. A., Gómez-Macpherson, H., Kuhn, N. J., Lázaro, R., León, F. J., Martínez-Mena, M., MartínezMurillo, J. F., Marzen, M., Mingorance, M. D., Ortigosa, L., Peters, P., Regüés, D., Ruiz-Sinoga, J. D., Scholten, T., Seeger, M., Solé-Benet, A., Wengel, R., and Wirtz, S.: European small portable rainfall simulators: a comparison of rainfall characteristics, Catena, 110, 100-112, doi:10.1016/j.catena.2013.05.013, 2013a.

Iserloh, T., Ries, J. B., Cerdà, A., Echeverría, M. T., Fister, W., Geißler, C., Kuhn, N. J., León, F. J., Peters, P., Schindewolf, M., Schmidt, J., Scholten, T., and Seeger, M.: Comparative measurements with seven rainfall simulators on uniform bare fallow land, Z. Geomorphol., 57, 11-26, doi:10.1127/03728854/2012/S-00085, 2013b.

IUSS Working Group WRB: Guidelines for constructing smallscale map legends using the WRB. World Soil Resources, $2^{\circ}$ ed. FAO, Rome, Italy, 2006.

IUSS Working Group WRB: Land Evaluation. Towards a revised framework. Land and Water discussion paper (6), $2^{\circ}$ ed. FAO, Rome, Italy, 2007.

IUSS Working Group WRB: World Reference Base for Soil Resources 2014. World Soil Resources Report 106, FAO, Rome, Italy, 2006.

Köppen, W. and Geiger, R.: Klima der Erde, Justus Perthes, Darmstadt, Germany, 1954.

Loewenherz, D. S.: Stability and the initiation of channelized surface drainage: A reassessment of the short wavelength limit, J. Geophys., Res., 96, 8453-8464, doi:10.1029/90JB02704, 1991.

Ludwig, B., Boiffin, J., Chadoeuf, J., and Auzet, A. V.: Hydrological structure and erosion damage caused by concentrated flow in cultivated catchments, Catena, 25, 227-252, doi:10.1016/03418162(95)00012-H, 1995.

Martínez-Casasnovas, J. A., and Poch, R. M.: Estado de conservación de los suelos de la cuenca del embalse Joaquín Costa, Limnetica, 14, 83-91, 1998.

Martínez-Casasnovas, J. A.: A spatial information technology approach for the mapping and quantification of gully erosion, Catena, 50, 293-308, doi:10.1016/S0341-8162(02)001340, 2003.

Martínez-Casasnovas, J. A., Antón-Fernández, C., Ramos, M.C.: Sediment production in large gullies of the Mediterranean area (NE Spain) from high-resolution digital elevation models and geographical information. Systems analysis, Earth Surf. Process. Landforms, 28, 443-456, doi:10.1002/esp.451, 2003.

Martínez-Casanovas, J. A., Ramos, M. C., and Ribes-Dasi, M.: On-site effects of concentrated flow erosion in vineyard fields: some economic implications, Catena, 60, 129-146, doi:10.1016/j.catena.2004.11.006, 2005.
Martínez-Casasnovas, J. A. Ramos, M. C., and Cots-Folch, R.: Influence of the EU CAP on terrain morphology and vineyard cultivation in the Priorat region of NE Spain, Land Use Policy, 27, 11-21, doi:10.1016/j.landusepol.2008.01.009, 2010.

Materechera, S. A.: Tillage and tractor effects on soil compaction in hortocultural fields used for peri-urban agriculture in a semi-arid environment of the North West Province, South Africa, Soil Till. Res., 103, 11-15, doi:10.1016/j.still.2008.09.001, 2009.

Mays, L. W.: Water Resources Engineering, 2nd edn., John Wiley and Sons, New York, 2010.

Menzel, A.: A 500 year pheno-climatological view on the 2003 heat wave in Europe assessed by grape harvest data, Meteorol. Z., 14, 75-77, doi:10.1127/0941-2948/2005/0014-0075, 2005.

Nachtergaele, J.: A spatial and temporal analysis of the characteristics, importance and prediction of ephemeral gully erosion, $\mathrm{Ph}$. D. thesis (unpublished), Department of Geography-Geology, K.U. Leuven, 2001.

Paroissien, J. B., Lagacherie, P., and Le Bissonnais, Y.: A regionalscale study of multi-decennial erosion of vineyard fields using vine-stock unearthing-burying measurements, Catena, 82, 159168, doi:10.1016/j.catena.2010.06.002, 2010.

Piccarreta, M., Capolongo, D., Boenzi, F., and Bentivenga, M.: Implications of decadal changes in precipitation and land use policy to soil erosion in Basilicata, Italy, Catena, 65, 138-151, doi:10.1016/j.catena.2005.11.005, 2006.

Poesen, J., Vandaele, K., and van Wesemael, B.: Gully erosion: importance and model implications, in: Modelling Soil Erosion by Water, edited by: Boardman, J. and Favis-Mortlock, D., NATO ASI Series, Vol. I 55, Springer-Verlag, Berlin, Heidelberg, 285311, 1998.

Prasuhn, V.: Soil erosion in the Swiss midlands: results of a 10-year field survey, Geomorphology, 126, 32-41, doi:10.1016/j.geomorph.2010.10.023, 2011.

Quinton, J. N., Govers, G., Van Oost, K., and Bardgett, R. D.: The impact of agricultural soil erosion on biogeochemical cycling, Nat. Geosci., 3, 311-314, doi:10.1038/ngeo838, 2010.

Quiquerez, A., Brenot, J., Garcia, J.-P., and Petit, C.: Soil degradation caused by a high-intensity rainfall event: Implications for medium-term soil sustainability in Burgundian vineyards, Catena 73, 89-97, 2008.

Raclot, D., Le Bissonnais, Y., Louchart, X., Andrieux, P., Moussa, R., and Voltz, M.: Soil tillage and scale effects on erosion from fields to catchment in a Mediterranean vineyard area, Agr. Ecosyst. Environ., 134, 201-210, doi:10.1016/j.agee.2009.06.019, 2009.

Richter, G. (ed.): Der Aufbau der Forschungsstelle Bodenerosion und die ersten Messungen in Weinbergslagen, in: University of Trier, Trier, Germany, 1-17, 1975.

Richter, G.: On the soil erosion problem in the temperate humid area of Central Europe, GeoJoumal, 4, 279-287, 1980a.

Richter, G.: Three years of plot measurements in vineyards of the Moselle region some preliminary results, Z. Geomorphol., 35, 81-91, 1980b.

Richter, G.: Combating Soil Erosion in Vineyards of the MoselRegion, Universität Trier, Trier, 1991.

Richter, G. and Negendank, J. F. W.: Soil erosion processes and their measurement in the German area of the Moselle river, Earth Surf. Processes, 2, 261-278, doi:10.1002/esp.3290020217, 1977. 
Ries, J. B., Seeger, M., Iserloh, T., Wistorf, S., and Fister, W.: Calibration of simulated rainfall characteristics for the study of soil erosion on agricultural land, Soil Till. Res., 106, 109-116, 2009.

Ries, J. B., Iserloh, T., Seeger, M., and Gabriels, D.: Rainfall simulations constraints, needs and challenges for a future use in soil erosion research, Z. Geomorphol., 57, 1-10, doi:10.1127/03728854/2013/S-00130, 2013a.

Ries, J. B., Marzen, M., Iserloh, T., and Fister, W.: Soil erosion in Mediterranean landscapes. Experimental investigation on crusted surfaces by means of the portable wind and rainfall simulator, J. Arid Environ., 100-101, 42-51, 2013b.

Rodrigo Comino, J.: Cuantificación de los gradientes térmicos a nivel superficial a lo largo del Rheinland-Pfalz (RenaniaPalatinado, Alemania), Baetica, 35, 75-98, 2013.

Rosell, R. A., Gasparoni, J. C., and Galantini, J. A.: Soil organic matter evaluation, edited by: Lal, R., Kimble, J., Follett, R., and Stewart, B., Assessment Methods for Soil Carbon, Lewis Publishers, USA, 311-322, 2001.

Ruiz-Sinoga, J. D. and Martínez-Murillo, J. F.: Effects of soil surface components on soil hydrological behavior in a dry Mediterranean environment (Southern Spain), Geomorphology, 108, 234-245, doi:10.1016/j.geomorph.2009.01.012, 2009.

Sánchez-Moreno, J. F., Mannaerts, C. M., Jetten, V., and Löffler-Mang, M.: Rainfall kinetic energy-intensity and rainfall momentum-intensity relationships for Cape Verde, J. Hydrol., 454-455, 131-140, doi:10.1016/j.jhydrol.2012.06.007, 2012.

Sauerborn, P. Erosivität der Niederschläge in Deutschland, Ein Beitrag zur quantitativen Prognose der Bodenerosion durch Wasser in Mitteleuropa, edited by: Bonner Bodenkundliche Abhandlungen Band, 13, Bonn, Germany, 1994.

Schröder, D.: Soils and cultivation of land in the region of Trier, in: Combating Soil Erosion in Vineyards of the Mosel-Region, edited by: Richter, G., Universität Trier, Trier, 25-41, 1991.

Seeger, M.: Uncertainty of factors determining runoff and erosion processes as quantified by rainfall simulations, Catena, 71, 5667, doi:10.1016/j.catena.2006.10.005, 2007.

Senciales, J. M. and Ruiz-Sinoga, J. D.: Análisis espacio-temporal de las lluvias torrenciales en la ciudad de Málaga, B. Asoc. Geogr. Esp., 61, 7-24, 2013.

Takken, I., Beuselinck, L., Nachtergaele, J., Govers, G., Poesen, J., and Degraer, G.: Spatial evaluation of a physicallybased distributed erosion model LISEM, Catena, 37, 431-447, doi:10.1016/S0341-8162(99)00031-4, 1999.

Torri, D., Borselli, L., Calzolari, C., Yanez, M. S., and Salvador Sanchis, M. P.: Land use, soil quality and soil functions: effect of erosion, in: Man and Soil in the Third Millennium, edited by: Rubio, J. L., Morgan, R. P. C., Asins, S., and Andreu, V., Proceedings of the 3rd International Congress of the European Society for Soil Conservation, Valencia, Spain, Geoforma Ediciones, Logroño, Vol. I, 131-148, 2002.

Tropeano, D.: Soil erosion on vineyards in the Tertiarya Piedmontese basin (northwestern Italy). Studies on experimental areas, Catena Supp, 4, 115-127, 1983.
Unwin, T.: Wine and the Vine: an Historical Geography of Viticulture and the Wine Trade, Routledge, Taylor and Francis Group, New York, 1996.

Urhausen, S., Brienen, S., Kapala, A., and Simmer, C.: Climatic conditions and their impact on viticulture in the Upper Moselle region, Climatic Change, 109, 349-373, doi:10.1007/s10584011-0059-z, 2011.

Van Dijck, S. J. and van Asch, W. J.: Compactation on loamy soils due to tractor traffic in vineyards and orchards and its effect on infiltration in southern France, Soil Till. Res., 63, 141-153, doi:10.1016/S0167-1987(01)00237-9, 2002.

Van Oost, K., Quine, T. A., Govers, G., De Gryze, S., Six, J., Harden, J. W., Ritchie, J. C., McCarty, G. W., Heckrath, G., Kosmas, C., Giraldez, J. V., da Silva, J. R., and Merckx, R.: The impact of agricultural soil erosion on the global carbon cycle, Science, 318, 626-629, doi:10.1126/science.1145724, 2007.

Vandekerckhove, L., Poesen, J., Oostwoud Wijdenes, D., and de Figueiredo, T.: Topographical thresholds for ephemeral gully initiation in intensive cultivated areas of the Mediterranean, Catena, 33, 271-292, doi:10.1016/S0341-8162(98)00068-X, 1998.

Vandekerckhove, L., Poesen, J., and Govers, G.: Medium-term gully headcut retreat rates in Southeast Spain determined from aerial photographs and ground measurements, Catena, 50, 329 352, doi:10.1016/S0341-8162(02)00132-7, 2003.

Vermessungs- und Katasterverwaltung Rheinland-Pfalz: BasisDLM, DLM50, Hauskoordinaten, Hausumringe, DGM, LiKaV, LiKa-R, DTK5, DTK25, DTK50, TK100, DOP, Übersichts-/ historische-Karten, Trier, Germany, 2013.

Vogt, E. and Schruft, G.: Weinbau, Eugen Ulmer GmbH and Co, Stuttgart, 2000.

Wainwright, J.: Infiltration, runoff and erosion characteristics of agricultural land in extreme storm events, SE France, Catena, 26, 24-47, doi:10.1016/0341-8162(95)00033-X, 1996.

Wang, K., Zhang, C., and Weidong, L.: Predictive mapping of soil total nitrogen at a regional scale: a comparison between geographically weighted regression and cokriging, Appl. Geogr., 42, 73-85, doi:10.1016/j.apgeog.2013.04.002, 2013.

Wicherek, S.: Viticulture and soil erosion in the North of Parisian Basin. Example: The mid Aisne Region, Z. Geomorphol. Suppl., 83, 115-126, 1991.

Wischmeier, W. H. and Smith, D. D.: Predicting Rainfall Erosion Losses. A Guide to Conservation Planning, Agriculture Handbook, 537. USDA-SEA, Washington, DC, 1978.

Wirtz, S., Seeger, M., and Ries, J. B.: Field experiments for understanding and quantification of rillerosion processes, Catena, 91, 21-34, doi:10.1016/j.catena.2010.12.002, 2012. 